\title{
Advanced Proposals to Improve Advanced Directives in Portugal
}

\author{
João Carlos Macedo a\# \\ DOI: $10.9734 / \mathrm{bpi} / \mathrm{idmmr} / \mathrm{v} 5 / 1691 \mathrm{~A}$
}

\begin{abstract}
This article describes the current state of Advance Directives (living wills and/or attorney health care in the event of inability to express one) in Portugal. It investigates the reasons for the low number of registered advance directives and proposes two ways to increase citizens' adherence: Setting up a counselling in the national health system and the standard form.
\end{abstract}

Keywords: Advance directives; living will; attorney health care; counselling; proposal form.

\section{ADVANCE DIRETIVES IN PORTUGAL}

Advance directives (AD) are the ultimate expression of exercising autonomy while also respecting informed consent. This instrument originated in the United States in the mid-1970s, specifically with a human-rights lawyer named Luis Kutner. He began with the common law and constitutional law premises that "the law provides that a patient may not be subjected to treatment without his consent (...). The challenge was what to do about patients who no longer were capable of making health care decisions. He suggested that the individual should indicate in writing ahead of time the extent to which he or she would consent to treatment. He referred to the document as a "living will," "a declaration determining the termination of life," or a "testament permitting death,"among other names" [1].

So the $A D$ provide an individual a means of expressing his or her wishes for medical treatment when he or she is no longer able to make those wishes known due to incapacity [2].

The disclosure of the AD has been making its way in the USA and only more recently started to be implemented in several European countries [3].

Only at the beginning of the 21st century was it possible for portuguese society to have access to this instrument of prospective autonomy Portugal ratified in 2001 the Convention for the protection of human rights and dignity of the human being with regard to the application of biology and medicine: convention on human rights and biomedicine (Oviedo Convention) [4]. Only then could the Portuguese write an AD under Article 9 which stated: "Previously expressed wishes -The previously expressed wishes relating to a medical intervention by a patient who is not, at the time of the intervention, in a state to express his or her wishes shall be taken into account". However, this written document was not binding on health professionals.

Finally, the advance directives were legalized in Portugal, in 2012, by Law $n^{\circ}$. 25/2012 of 16 July [5]. According to the Portuguese AD Law, any citizen over eighteen years old and duly capable may declare in advance, and in a clear, conscious and informed manner, his or her wishes regarding medical care, by preparing an advance directive. These directives may take the form of a living will and a health care power of attorney [5]. The law states that AD can take two forms: living will (LW) and / or appointment of attorney health care $(\mathrm{AHC})$. Also determines that $A D$ can be revoked at any time and has five years of validity.

\footnotetext{
"Adjunct Professor

${ }^{a}$ Nursing School, University of Minho, Portugal.

${ }^{*}$ Corresponding author: E-mail: joaomacedo71@gmail.com;
} 
The AD can be written in free text or use an optional Ministry of Health form [6].

Citizens can declare that their advance directive is effective when they are in one or more of these situations:

- I have been diagnosed with terminal incurable disease

- Unconsciousness due to irreversible neurological or psychiatric illness complicated by complications respiratory, renal or cardiac;

- There are no expectations of recovery in the clinical evaluation by members of the medical team. caregiver according to state of the art;

- Other situations.

Then the citizen can indicate some instructions to health professionals, like:

- Not undergo artificial supportive treatment of vital functions;

- Not to be subjected to futile treatment, useless or disproportionate in their clinical condition and in accordance with good professional practice, particularly with regard to basic life support measures and artificial feeding and hydration measures that only aim to retard the natural process of death;

- Receive adequate palliative care

- Not be subjected to treatments that are in the experimental phase;

- Authorize or refuse participation in scientific research programs or clinical trials;

Concerning the $\mathrm{AHC}$, the portuguese legislation say that anyone can appoint one or more persons, giving them representative powers to decide on health care to receive, or not to receive, when unable to express their will personally and autonomously. The law state that AHC decisions must be respected by healthcare professionals. In case of conflict between the provisions set forth in the LW and the will of the AHC, the LW prevails.

Finally, in 2014 the Health Ministery created a database, a National Register of Advance Diretives [7] allowing citizens to have their AD accessible at any hospital in the country.

\section{THE ADVANCE DIRECTIVE: NUMBERS AND CAUSES}

According to the latest data, early 2020, Portugal has registered around 29000 AD. Women with 19 301 records, men with 10046 [8].

Notwithstanding some national bibliography that was emerging for citizen consultation [9-11] the numbers reveal the poor adherence of the portuguese to the advance directives. There are certainly multiple factors contributing to this case. Being aware of the low numbers of $A D$ in the portuguese population, here are some of the likely underlying causes:

1. We still continue to live in a death denial society; [12-13]

2. There is a need to promote education for death so that this subject can be discussed since childhood. [12- 13]. Talking about the end of life is something that is not in people's goals, much less make the decision to think about the care you want or refuse when you are in a situation where you can not communicate your wishes;

3. We still have a very paternalistic paradigm in health care. The exercise of autonomy is not yet properly developed in the practice of care; [14-15]

4. The population's health literacy level is low. There are fringes of the digital illiteracy population. In this regard, people have a hard time writing their directives; [16 -19]

5. Portuguese knowledge about autonomy in end-of-life care and particularly about $A D$ is very low. Recent studies point to values of around $1 \%$. [14,15,20,21].

6. The Health Ministry did not make a good promotion campaign, on the Internet and social networks and forgot about people who have digital illiteracy; [22].

7. Health professionals do not have adequate training for counseling; [23]

8. The form proposed by the Health Ministry is complex and unintuitive; [6] 
9. The lack of an advance directives guide. A guide with explanations of advance directives would allow citizens to draw up the document with more information and awareness. In Spain, in the Andaluzia region, the Ministry of Health has developed a guide for AD that greatly facilitates citizens; [24].

10. The lack of obtaining counselling from a health professional in the national health system so that the citizen can prepare the AD.

\section{INCREASE ADVANCE DIRECTIVES: COUNSELLING AND FORM PROPOSAL}

\subsection{Counselling: The nurses' role}

One of the predominant factors in the lack of adherence of citizens to $A D$ is related to $A D$ literacy. From our perspective, it seems that the Portuguese health system does not provide a place where citizens can obtain the necessary advice to prepare their AD. Our contribution is towards the creation of a counselling consultation in the Community Care Unit of the Health Centres. These units are designed to "... provide health care and psychological and social support, at home and in the in situations of greater risk or physical and functional dependency or disease that requires close monitoring, and also act in health education in the integration of family support networks and in the implementation of mobile intervention units "[25].

These care units, which are part of primary health care, are mainly staffed by nurses. Nurses are a highly qualified professional group to provide counselling in end-of-life care. On the other hand, within the scope of health education that nurses develop in this community care unit, this task would be framed and would empower the citizens' literacy level in the exercise of autonomy in end-of-life care. In addition, this counselling in this primary health care unit is much more favourable to the preparation of a well-reflected $A D$, without pressure and mediated by a health professional. Not dismissing the idea of citizens being able to perform their $A D$ in hospital or in a palliative care unit [23], we believe that reflection on end-of-life care and particularly on AD should be performed in a calm environment, without the expectation of a hospital admission. In this context, the offer of these counselling services in community care units with properly trained nurses is the most appropriate option to increase the levels of adherence to $A D$ in Portugal.

In addition to this incremental measure, we believe that the citizen should have a more intuitive tool for drafting ADs. In this sense, we leave below a small contribution, a form proposal, which was inspired by various models existing in European countries. However, the biggest contribution was from the Spanish model, more specifically from Andaluzia [24].

\subsection{Form proposal}

\section{Advance Directive}

Under and for the purposes of Law No. 25/2012 of 16 July this document reflects my early manifestation of conscious, free and enlightened will with regard to caring that I wish to receive, or do not wish to receive, if for any reason unable to express my will personally and autonomously.

This document, which I subscribe to being of legal age and capable and not being prohibited or disabled by psychic anomaly, and unilateral by me and freely revocable at any time. I know that this document is valid for a period of five years.

Personal considerations on end of life values: 


\section{IDENTIFICATION}

Name:

Doc.Ident. $n^{0}$

Validity:

Health $\mathrm{n}^{\mathrm{0}}$ : Nationality:

Address:

Postal Code: Date of Birth:

E-mail:

\section{WANT TO APPOINT MY ATTORNEY HEALTH CARE}

Name:

Ident Doc. No. Validity:

Nationality:

Health n.. :

Address:

Postal Code:

Country:

Tel.:

E-mail:

Signature of health care attorney

\section{CLINICAL SITUATION IN WHICH ADVANCE DIRECTIVES IS EFFECTIVE}

When I find myself unable to express my will autonomously as result of my state of physical and / or mental health, and if one or more of the following conditions ocurr:

Mark with $\mathbf{X}$ the applicable assumptions below

I have been diagnosed with terminal incurable disease

There are no expectations of recovery in the clinical assessment by team members according to state of the art

Severe and irreversible brain damage (irreversible coma, permanent vegetative state)

Degenerative disease of the nervous system in advanced phase

Degenerative disease of the neuromuscular system in advanced phase

$\square$ Immunodeficiency in advanced phase

Other serious and irreversible diseases or conditions similar to those above

Another clinic situation:

\section{HEALTH CARE INSTRUTIONS RECEIVING/NOT RECEIVING}

I direct the health care providers to withhold and withdraw treatment that merely prolongs my dying.

Thus, I express my clear and unambiguous desire to:

Mark with $\mathbf{X}$ the applicable assumptions below

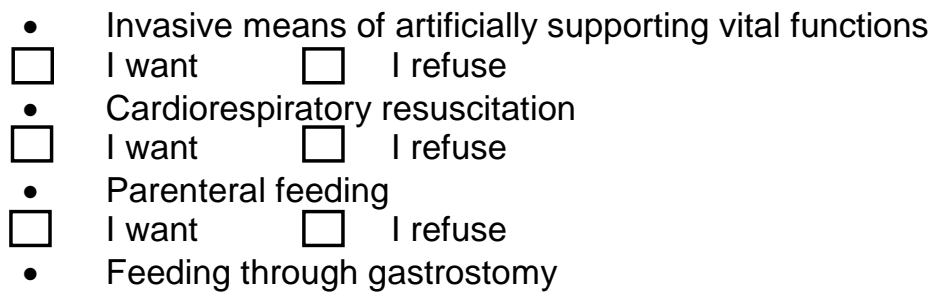




$\square \quad$ I want
$\square$ I refuse
$\square \quad$ I want
Intravenous hydration
I want
Renal clearance techniques (hemodialysis / peritoneal dialysis)
$\square \quad$ I want
Pain relief care and comfort for a serene death
$\square \quad$ I want
Palliative sedation I refuse
$\square \quad$ I want

Another treatment:

Other personal considerations:

\section{CONCLUSION}

AD in Portugal is still a young tool in the exercise of citizen autonomy. Several factors are present for the lack of adherence of the Portuguese. There is a need to continue to investgate this phenomenon and try to find proposals that can increase the level of adherence to $A D$ and, on the other hand, contribute to the respect self-determination and human dignity. Our contribution in this paper is in this direction: to have counselling in the preparation of $A D s$ and also to present easier instruments for the completion of ADs.

\section{COMPETING INTERESTS}

Author has declared that no competing interests exist.

\section{REFERENCES}

1. Sabatino CP. The evolution of health care advance planning law and policy American Bar The Milbank Quarterly. 2010; 88(2): 211-239.

2. Casey DA, Walker DM. The clinical realities of advance directives. Widener Law Review. 2011; 17(2):429-442.

3. Andorno R, Biller-Andorno N, Brauer S. Advance care directives: Towards a coordinated European policy. Journal of Health Law. 2009;16:207-227.

DOI: $10.1163 / 157180909 \times 453053$

4. Convention for the protection of human rights and dignity of the human being with regard to the application of biology and medicine: convention on human rights and biomedicine. - Resolução da Assembleia da República n. 1/2001 Diário da República n.ํ 2/2001, Série I-A de 2001-0103, p14-36

Available:https://dre.pt/pesquisa/-/search/235128/details/maximized (accesseded on 10/01/2020)

5. Lei n. 25/2012, Diário da República n.ำ136/2012, Série I de 2012-07-16, p. 3728 - 3730

Available:https://dre.pt/pesquisa//search/179517/details/normal?q=Lei+n.\%C2\%BA\%2025/2012 +de+16+de+julho (accesseded on 05/01/2020)

6. Available:https://spms.min-saude.pt/content/uploads/2016/05/Rentev_form_v0.5.pdf (accesseded on 12/01/2020) 
7. Portugal, Portaria n. 96/2014 - Diário da República n.ำ 85/2014, Série I de 2014-05-05, p. $2637-2639$

Available:https://dre.pt/pesquisa/-/search/25343768/details/maximized (accesseded on 13/01/2020)

8. Available:https://www.spms.min-saude.pt/2020/01/o-testamento-vital-e-um-direito-dosportugueses/ (accesseded on 13/01/2020)

9. Santos L. Testamento Vital- O que é? Como elaborá-lo. Porto: Sextante Editora; 2011.

10. Nunes R, Melo HP. Testamento Vital. Coimbra: Almedina; 2011.

11. Nunes L. E quando eu não puder decidir? Lisboa: FFMS; 2016.

12. Macedo JC. Death Education - An approach from the work of Elisabeth Kübler-Ross. Berlin: LAP LAMBERT Academic Publishing; 2020.

13. Macedo JC. An approach to death education. MOJ Gerontology \& Geriatrics. 2019;4(6):276278.

DOI:10.15406/mojgg.2019.04.00220

14. Laranjeira C, dos Anjos Dixe M, Gueifão L, Caetano L, Passadouro R, Gabriel T, Querido A. Development and psychometric properties of the general public's attitudes toward advance care directives scale in Portugal. Journal of Public Health Research. 2021 Jan 14;10(1).

15. Laranjeira C, Dixe MD, Gueifão L, Caetano L, Passadouro R, Querido A. Awareness and Attitudes towards Advance Care Directives (ACDs): An Online Survey of Portuguese Adults. Healthcare 2021 Jun (Vol. 9, No. 6, p. 648). Multidisciplinary Digital Publishing Institute.

16. Espanha R, Ávila P. Health Literacy Survey Portugal: a contribution fot the knowledge on health and comunications. Procedia Computer Science. 2016;100:1033-1041. DOI:10.106/j.procs.2016.09.277

17. Paiva, D et al. Limited Health Literacy in Portugal Assessed with the Newest Vital Sign. Acta Médica Portuguesa. 2017;30(12): 861-869.

Doi:https://doi.org/10.20344/amp.9135

18. Tunzi M. Advance care directives: realities and challenge in central California. Journal Clinic Ethics. 2011;22(3):239-248

19. Macias,E A; Armaza, J A; Beriain, I M Aspectos bioético-jurídicos de las instrucciones previas o testamento vital en el contexto normativo español Acta Bioethica. 2015;21 (2):163-172.

20. Capelas MLV, Coelho SPF, Silva SCFS. da, Ferreira CMD, Pereira CMF, Alvarenga MISFe Freitas M. de S. Os portugueses e o Testamento Vital, Cadernos de Saúde. 2017;9:44-53. DOI: 10.34632/cadernosdesaude.2017.2864.

21. Available:https://www.spms.min-saude.pt/2020/01/o-testamento-vital-e-um-direito-dosportugueses/ (accessed on 15/01/2020)

22. Ólafsdóttir, KL et al .Integration-nurse-facilitated advance care planning for patients newly diagnosed with advanced lung cancer. International Journal of Palliative Nursing. 2018. 24(4):170-177. DOI:10.12968/ijpn.2018.24.4.170

23. Available:https://www.juntadeandalucia.es/organismos/saludyfamilias/areas/calidadinvestigacion-conocimiento/calidad-sistema-sanitario/paginas/webrva.html (accessed on 15/01/2020)

24. Besirevic, V. End-of-life in the 21st century: advance directives in universal rights discourse. Bioethics. 2010;24 (3):105-112. DOI:10.1111/j.1467-8519.2010.01806.x

25. Portugal. Diário da República, 2. e Série - n.ำ 74, 16 de abril de 2009, Ministério da Saúde Despacho n.. 10142/2009, 15438-15440.

Available:https://dre.pt/dre/analise-juridica/despacho/10143-2009-2216310

(C) Copyright (2022): Author(s). The licensee is the publisher (B P International). 